\title{
RELIGIOUS TOLERANCE THROUGH STONE SCULPTURE PRODUCTION: THE CASE OF INDONESIAN SCULPTORS
}

\author{
RIZA ISTANTO*, TRIYANTO \\ Post-graduate of Art Education, Universitas Negeri Semarang
}

\section{Abstract}

The purpose of this research is to analyze the value of tolerance reflected in the stone-sculpture production in Muntilan. This study used a sociology research approach with an ethnographic research design. The data collection techniques were conducted through ethnographic observation and interviews as well as document data. The results showed that the stone craft production in Muntilan is local wisdom that reflects the value of tolerance. Most of the rock artisans are Moslems, but they continued stone sculpture production that is part of the Hindhu-Buddist tradition. The product is oriented towards consumer demand, which is a contrast to the beliefs of sculptors such as Buddha statues, Hindu deities, statues of Jesus, as well as statues of other religions. The sculptures separated themselves between work and religious issues. It illustrates an open attitude as well as tolerance in accepting and understanding differences. Such local wisdom with a long-standing tolerance value in the community is a potential for community development in realizing a harmonious and peaceful life.

Tujuan penelitian ini adalah menganalisis nilai toleransi yang tercermin pada aktivitas patung batu di Muntilan. penelitian ini menggunakan pendekatan penelitian sosiologi dengan desain penelitian etnografi. Teknik pengumpulan data melalui observasi

\footnotetext{
* Corresponding author: Post-graduate of Art Education, Universitas Negeri Semarang, Sekaran, Gunungpati, Semarang, Indonesia, 50229. E-mail: istantoriza8@gmail. com.
} 
dan wawancara etnografi serta penggalian data dokmen. Hasil penelitian menunjukkan bahwa produksi patung batu di Muntilan merupakan kearifan lokal masyarakat yang merefleksikan nilai toleransi. Kebanyakan perajin batu beragama Islam namun tetap memproduksi patung batu yang merupakan tradisi Hindu-Budha. Produk yang dihasilkan berorientasi pada permintaan konsumen yang bertolak belakang dengan kepercayaan pematung seperti arca Budha, Dewa-dewi Hindu, patung Yesus, serta patung bercorak agama lainnya. Para perajin memisabkan diri antara pekerjaan dengan persoalan agama. Hal tersebut menggambarkan prilaku terbuka serta toleran dalam menerima dan memahami perbedaan. Kearifan lokal dengan nilai toleransi yang telah lama bertahan di masyarakat tersebut merupakan potensi bagi pembinaan masyarakat menuju kedewasaan hidup.

Keywords: local wisdom; Muntilan; sculpture production; tolerance value.

\section{Introduction}

Indonesia is a heterogeneous country with a diversity of cultures, tribes, races, and religions. The difference is an absolute necessity for a plural society, such as the people of Indonesia. On the one hand, diversity contributes to wealth and a lucrative culture when managed well, but on the other hand, it also triggers the conflict of divisions (see Rasimin 2016, 100). The remaining task for the Indonesian people is to maintain tolerance attitude among society.

In Indonesia, tolerance occupies an important role in all areas of life in social, cultural, political, economic, political, and religious matters. Tolerance can be interpreted as an open trait in understanding and accepting all forms of equality and distinction (Ruhana 2015; Sofiyev 2019). The manifestation of tolerance in the association of life among the religious people can be realized through each religion by recognizing the existence of other religions and respects all rights of adherents, and in the life 
of society. Each of the religious groups needs to have an attitude of mutual respect and appreciation (Maulidah 2014).

The results of a religious harmony survey in 2012 conducted by the Puslitbang religious life showed that the condition of religious harmony in Indonesia is in a fairly harmonious range (Ruhana 2015, 115). Various studies have shown that harmony and tolerance in similarities and differences in Indonesia are maintained by all Indonesian society, including the actions of Indonesian community initiatives through certain activities, such as those that are reflected in the production of stone sculpture in Muntilan.

The stone kriya in Muntilan is a cultural heritage of the Hindu-Buddhist era in Indonesia (Misgiya 2004), but many of the sculptors are now Muslim. The work is created based on consumer demand. It is common to have an opposite theme with the religion of artisans.

This study aimed to analyze the value of tolerance reflected in the stone-sculpture activities in Muntilan. The study used a sociology research approach with an ethnographic research design (Spradley 2007). The data collection techniques consisted of observations and ethnographic interviews and documentation. The technique of data validity was conducted through the triangulation method. The procedures of data analysis were taken through the reduction process, presentation, and verification of data with the interactive model (B. Milles and Humberman 2007).

The research was conducted at the production center stone sculpture in Muntilan, namely Tamanagung village. The observation technique was aimed at obtaining data on the physical and social images of the natural and societal environments in Muntilan, the environment, and activities of stone sculpture, as well as the stone sculpture produced by Muntilan people. 
Interviews with several speakers were conducted to obtain data on the tolerance values of sculptural makers in Muntilan. The first interview was for senior stone sculpture makers regarding history, worker processes, and interactions with stone sculpture makers, interactions with buyers, and interactions with communities around Muntilan. The second interview was for employees or sculpture workers regarding the process of making work and interaction of the surrounding environment. The third interview was for the local government on the diversity in Muntilan, the historical stone sculpture production in Muntilan, and Muntilan's response to the production of stone sculptures in Muntilan. From each informer, researchers collected the data about the participants' responses to sculpture makers to create different works with their beliefs.

Documentation was conducted to acquire some documents. The documents were obtained from magazines, government reports, and various documents. These documents were related to Muntilan's social-cultural data, a diversity of beliefs in Muntilan, as well as about the production of sculptures in Muntilan. The collected data was then analyzed to look for the embodiment of tolerance value in the production of statues in Muntilan. The value of tolerance includes the recognition of each believer acknowledging the existence of other religions and respecting all its adherence in social life. Every religious class reveals the attitude of appreciation and respect (Maulidah 2014, 201).

\section{The Condition of Social-cultural and Religion in Muntilan}

Muntilan is one of the districts in Magelang Regency, Central Java province. The location of Muntilan subdistrict has some intensity, namely Mungkid Sub-district in the west, district of Borobudur in the south, Dukun, and Salam district in the east and Sawangan Sub-district in the south (BPS Magelang 2017).

According to Ningtyas (2018) from the map of 1922, it is 
depicted that Muntilan environment is flanked by four rows of mountains; In the northern region of the Lemah mountains, in the east of Merapi Mountain and Merbabu Mountain, in the south of the Gendol Mountains and the Ukir mountains and Sipodang mountains in the west side. Circled by mountain ranges, Muntilan is surrounded by many rivers, among others; Blongkeng river, Pabelan river, Poetih River, and Droedjo river, which boils down to the Progo River.

The rivers are on Mount Merapi, which carries the material of lava fluid. Therefore, andesite stone and sand are abundant. The rocks are derived from the hot lava fluid that is drained from the mountain and then flows downwards and eventually freezes into rocks as well as sand. The number of rivers also makes Muntilan, agricultural, and plantations areas are so fertile.

The diversity of beliefs in Muntilan has been long, evidenced by several religious buildings such as Masjid and Pondok Pesantren, St Antonius Padua Catholic Church, Hok An Kiong Temple, and long-standing Ngawen temples in Muntilan. There are 11 mosques and 11 Mushalla, four churches and four chapels, and one temple (Muchtar and Burhani, 2016). This became a marker of harmony and tolerance that was continuously guarded by Muntilan people.

Figure 1

Some of the religious places in Muntilan

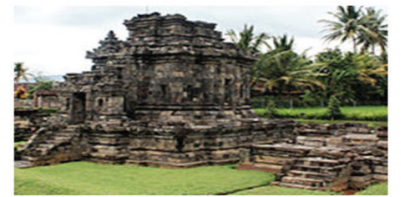

(a)

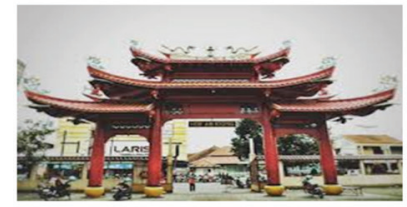

(c)

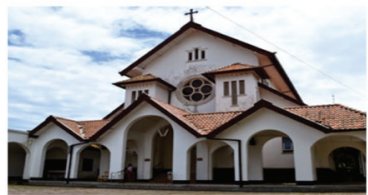

(b)

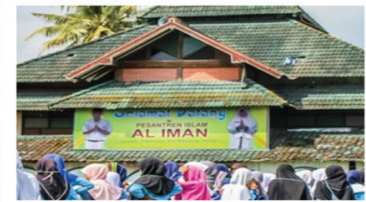

(d)

Vol. 27, No.1 (2019) 
(a) Ngawen temple, (b) Church of Santo Antonius Padua, (c) Pagoda of Hok An Kiong, dan (d) Islamic Boarding School of Al-Iman

Source: Researcher's Documentation, 2018

Muntilan is not only a community that maintains harmony and tolerance in religious diversity. The government of Muntilan district also participated in maintaining togetherness, harmony, and religious tolerance in Muntilan. On Saturday, 03 August 2013, at the oldest temple in Magelang Hok An Kiong held iftar together. The event was attended by several representatives of religious leaders such as Confucian, Hindu, Buddhist, Christian, Catholic, Islamic, and other religious believers. The event was held by the community, a group of Magelang and Muntilan people. The event began with a cross-religious gathering by Alisa Qotrunada Wahid (the eldest daughter of Gus Dur) and continued to breakfasting together (Parwito 2019).

As we can see from its history, Muntilan subdistrict is a region with the rapid development of the Catholic religion compared to other areas in Java. This is closely related to the nature of the abangan belief of Muntilan, the following explanation (Ningtyas 2018, 43).

The majority of Muntilan people are Muslims, but until the mid-20th century, there are still many people who do not do the worship or Islamic pillars. Muntilan is an area of Mataram that once entered the Vortenlanden area, so the number of people abangan is quite a lot. When the abangan people do not understand and live the teachings of Islam in earnest, it usually tends to have more interest in educating their children in the Mission school. Mission schools are more promising for indigenous people than government-owned schools. Meanwhile, in the school mission, the lessons about Catholicism are given intensively, and institutional, the conversion process in Muntilan began to have a clue.

It is no wonder that the Catholicism adopted by the community of Muntilan is about 936 people (BPS Magelang 2017). The 
Catholic of Saint Antonius Padua in Muntilan was completed in 1915, proving Ningtyas's statement (2018) above.

Today, the majority of Muntilan's people are Javanese and Islam (Shawma \& Setyono, 2014). This can be seen from the number of Muslims in Muntilan that reached 72726 people from a total population of 79136 people (BPS Magelang 2017). Muntilan Society has the type of culture of Javanese Negarigung, which prioritizes the smoothness of the arts and religious views that tend to be syncretic (Koentjaraningrat, 1994; Geertz, 1985; Triyanto, 2018). It is seen in the tradition of pilgrimage ceremony 1 Muharram in Gunung Pring village of Muntilan subdistrict.

Pilgrimage ceremony 1 Muharram in Gunung Pring village is done in commemoration of the death of Kiai Raden Santri and Kiai Jogo Rekso. The ceremonial form begins with Mujahadah, reading Yasin, and Tahlil then ended with prayer. After the prayer is completed, pilgrimage ceremony 1 Muharram is closed with processioning and providing tumpeng.

The grave of Kiai Raden Santri and Kiai Jogo Rekso are located in Gunung Pring village. It is located on the west side of Muntilan subdistrict, on a short hill overgrown by bamboo. To reach the grave complex, the visitors or pilgrims must go through hundreds of stairs. The grave complex of Gunung Pring is a protected cultural heritage object in Magelang Regency.

In addition to the church of Santo Antonius Padua and the grave complex in Gunung Pring, Muntilan District has some cultural heritage objects that have old historical values. The cultural heritage objects include Hok An Kiong temple, the grave of Pasteur Van Lith, and Ngawen temple.

Muchtar and Burhani (2016) added that the social condition of a community in Magelang Regency (especially Muntilan) could not be separated from the cultural characteristics of 
Negarigung culture, which is influenced by the tradition of Kraton Yogyakarta, so the nature of the Gotongroyongan. In the daily life of society is very prominent. Koentjaraningrat (2002, 59) mentions there are several types of activities in the community village, especially in Java that help each other between neighbors who live adjacent, for small jobs around the house and yard; (1) activities of help among family in circumcision event, marriages or other customary ceremonies around individual circles of life, and (2) spontaneous activities without demand and reward to help spontaneously at the time when villager is experiencing death or disaster. The manifestations are that art that reflects the culture of society such as topeng ireng, Kubro, Jathilan, dayakan and kuntulan are kinds of stonecraft.

Activities that reflect the value of any team in the form of art in Muntilan community materialized in the form of each other and exchanging system of energy between the actors in the production of art. Some folk arts are art that is held concerning certain traditional traditions or ceremonies, such as the art of Jathilan. Kuswarsantyo $(2014,50)$ explains that:

Functionally the art of Jathilan has an important role in the life of society as part of social activities, which is better known as ceremonial means, such as Merti Désa or clean village. The existence of Jathilan in the event Merti Désa gives social effect to the supporting community as a means of mutual assistance. The values of cooperation behind the arts are reflected in the efforts to give each other a shortage of artistic needs, such as the procurement of instruments, training places, and the procurement of costumes.

The relation to the stone craft in Muntilan is that the activity of helping each other is reflecting the value of cooperation. The production of stone crafts involves the social society, consisting of stone-breaking laborers, sculptors and stone carvers, merchants and entrepreneurs, as well as skilled craftsmen. The 
production of stone crafts is teamwork. Each individual helps to complete the work of making craft products. For example, the craftsmanship of stone is on a large scale. The large-scale stone craft projects involve beginner and expert sculptors. Beginner sculptors work together in completing the basic sculpting tasks. After that, the details of each particular piece were completed by expert sculptors with intense coordination between the two teams.

\section{The Diversity of Stone Craft Products in Muntilan: The Reflection of Tolerance Value}

Stone Craft is one form of the traditional art of community in Muntilan subdistrict. This art has been growing in the community since the time of Indonesia Hindu-Buddhist (Misgiya 2004). It is located in Muntilan subdistrict, precisely along the edge of the highway from Magelang to Yogyakarta.

The skill of stone carving was inherited hereditary by the ancestors of temple makers in Java. Initially, in the year 1955, there are only a few villagers in Prumpung, Tamanagung, District Muntilan, District Magelang, Central Java that works as Jlagra (the man who is stone crusher) who also made a simple product (Supeno 1990). Stone products produced at that time are still simple, which is limited to equipment such as cowek or cobek, lumpang or lesung, gravestone or Nisan, and various other things that are sold out at that time. Finally, it develops into a stone craft that has a high economic value such as reliefs, statues, sculptures, and others in Muntilan. Nowadays, the sculptures in Muntilan have reached local and international markets.

Stone Craft Products created by the community Muntilan is a three-dimensional carving product made of stone with chisel technique. Various products produced can be classified into handicraft products for household and craft objects for art. Handicraft products for household as well as cobek, lesung, 
umpak, and other objects, as well as crafts for the arts such as statues, reliefs, the stupa, and various kinds of the stone craft of garden ornaments.

Stonecraft that is intended as an art object can be classified into several categories of themes, namely, enshrinement, religious, legend, animals, and so on. In addition to these themes, there are also forms of garden ornaments such as large jars, gutters, lighting spots, as well as gates or fences. Among these themes, the theme of the enshrinement is a special product of Muntilan, such as Buddhist statues, Hindu deity's statue, reliefs, temple ornaments, and stupas.

Many stone products produced, sculpture products is a product that is often made and much in demand, especially with regard to the forms of such as Buddhist statues, Hindu deities, and reliefs, along with the description of the form. The product is a statue of stone sculpture is a product of a craft that tangible statues of gods-goddess Hindhu and Buddha. The statues resemble human figures that are composed of heads, bodies, and limbs, as well as legs. Each statue formed has different characteristics, depending on the type of character depicted. The difference lies in the position, the attributes, the Mudra, and the other sections. The product is made of statues of Buddha, Durga, Wisnu, Ganesa, Dwalapala, Prajnaparamita, etc.

Buddha sculpture is a kind of product that is often ordered. The shape is just a part of the head; some are intact from head to toe. Its size varies from a small size of about $30 \mathrm{~cm}$ or more. The Buddha statue often-ordered is a Buddhist statue in a sitting position. There is hair on its head that is accompanied by a kind of bun (Usnisa). The eyes are looking down; between the two eyes there is a similar small sign called Urna and the long ear that extend to downward. The position of the statues depicted there is sitting, standing and there is also a position of sleep- 
ing with the position of the hand that adjusts the Mudranya. If the Mudranya Dharmacaraka hand attitude spins the wheel of darma, Bhumisparca is a hand attitude that took the earth as a witness, Abhaya is a calming hand attitude, Dhyana is a hand attitude of ascetic, and Wara is hand attitude that gives grace. At the bottom, there are some of the petals that are decorated with lotus flowers.

The statue of Hindhu gods also has the same structure. The depiction in a position stood on a lotus-shaped base in bloom. There are also those who are sitting in the position of Prajnaparamita. Hindu statues have special features in the background. The statue of Hindhu is also depicted wearing accessories and jewelry. The accessories and jewelry were formed with a delicate-looking stylus. The same thing is also depicted in the work of sculpture. Statues are made of figures such as portraits. Gajah Mada, the ancient man, and so forth.

Figure 2

Diversity of stone craft

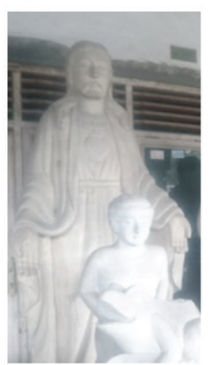

(a)

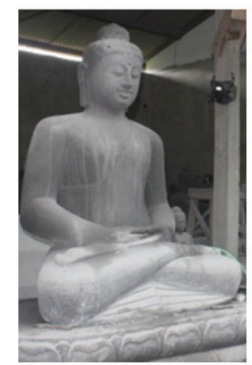

(b)

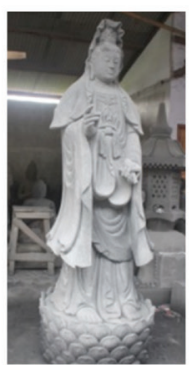

(c)

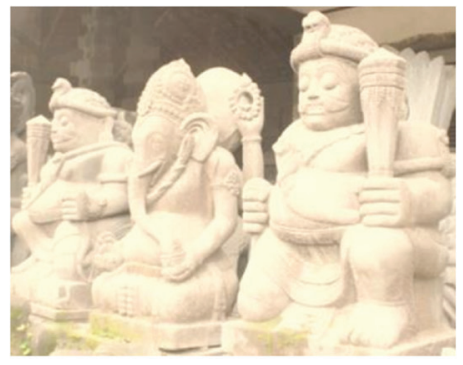

(d)

(a) Jesus statue, (b) Budha statue, (c) Kwanin statue, and

(d) Hindu deity's statue.

Source: Researcher's Documentation, 2018

Relief made from pieces of stone beams arranged in a certain size. Stone beams are arranged with interlocking techniques forming a large piece of stone. The relief field is usually a square 
or rectangular shape of varying size; most of the relief orders have a wide size of the field of chisels above 1.5 square meters. The structure is composed of decorative frames surrounding the chisel field and the content of the story.

The unique thing to observe is the religious theme; various religious symbols are made by stone craftsmen in Muntilan, including Buddha statues, Hindu deities, Jesus, and Dewi Kwanin. Various themes and types of stone crafts created by craftsmen of Muntilan are a reflection of artisans' character that is opened and tolerant to appreciate and to accept consumer orders.

There are some interviews conducted by the author with some expert interviewees. The interview data indicate that there is a tolerance and open mind attitude from the stone craftsmen in Muntilan in understanding the differences. The author use abbreviation to the identity of speakers with the initials DJ, KIP, and $\mathrm{MH}$.

According to DJ, the skill of making stone crafts is a legacy of ancestors. Here's the statement.

For the craftsmen, including myself, the skill of making stone crafts is a belief of parents and grandmother who have long been handed down to us. This is our legacy and must be handed down to each generation. Making stone crafts means appreciating and developing the ancestral heritage of ancestors. We should respect the religion we believe, should not we? This is what I did.

KIP argues that belief has nothing to do with work. Here is the further KIP statement.

I do not question about religion, and I make stone crafts are the demands of work. I only obey consumer demand; as long as I can I will strive to make it. For the Friends of the craftsmen, I think so too, the question of religion is not a barrier for us to work.

The same answer is also expressed by the $\mathrm{MH}$. 
The craftsmen in Muntilan have been familiar with the Borobudur temple, which is different from my religious background and most of my friends. Even the religion in Muntilan is different. For us, the orders that come from consumers with a diverse religious setting will be received gladly.

The above statements show the tolerant attitude of DJ, KIP, and $\mathrm{MH}$ in a stone carving activity.

In addition to senior sculpture makers, there are also responses from government agencies, stone chisels, and Muntilan communities on this. There are three interviewees representing the government, sculptor, and communities that authors abbreviate into ST, PN, ST. There are following responses which describe the attitude of respecting others ' beliefs regardless of their own beliefs.

According to ST, the stone statue practitioner in Muntilan was able to put his belief status, and when dealing with others, the following authors presented his interview results.

Speaking of the production of sculptures in Muntilan, there is a lot to consider. Muntilan Society is diverse, and experience about the stone is very different. For artists or creators who pursue long-standing art, making stone sculptures is an activity that can distribute the needs of art. Staying out of the law is permissible or not, for the religious sculpture makers, they do not sculpture the statues, but they prefer to make mortar, lanterns, and fountains. But each worker blended into one.

The same perspective is also conveyed by PN. According to $\mathrm{PN}$, the production of sculpture in Muntilan has benefited the community in providing employment and maintaining togetherness.

I hear the voices of people carving rocks every day. It is already a regular. I see this is very good, especially for the society. Many of the communities benefited from the production of this stone sculpture. Despite the religious issues, I see the harmony between individuals. Everyone interacts, no matter the background of the religion. 
As ST said that the production of sculpture in Muntilan has long been preserved from the family to the community.

I think the historical background and this habit have long been maintained. Carving stone activities familiarize people (the makers of stone statues) to keep working without compromising religious issues.

\section{Discussion}

The manifestation of tolerance in the association of life among the religious people can be realized by means of each religion to recognize the existence of other religions and respects all rights of adherents 1) and in the Life of society, each of the religious groups has an attitude of mutual respect and appreciation 2) (Maulidah, 2014, 201). Communities of Muntilan have various religious backgrounds. Diversity in Muntilan has an influence on how to do artistry, especially in producing stone crafts. From the various evidence and explanations that have been shown above, the tolerant attitude that the Muntilan society has to underlie the craftsmen in producing stone crafts. It is seen from the tradition of making stone crafts, which is a cultural heritage of Hinduism-Buddhism, but many of the stone craft is now Muslim. From the statement, it was concluded that the stone craftsmen in Muntilan had an open mind in understanding the differences.

Historical factors become one of the important issues that create a tolerance attitude in Muntilan. Stone craft has been inherited since the time of Hindhu-Buddha until now. In addition, Muntilan has the cultural character of negarigung with differences. From the historical records expressed by Ningtyas (2018) implied that the Muntilan community has a cultural characteristic of negarigung that resulted in the conversion of understanding between Muslim and catholic teachings. This understanding makes the community is welcomed to accepting the difference. 
The explanation of Ningtyas (2018) continues and reveals that the Muntilan community was living in Muslim life, was not earnest, and tends to have more interest in educating their children in mission schools. Mission schools are more promising for indigenous peoples than government-owned schools. Meanwhile, in school mission lessons about Catholicism are given intensively and instituted, so the conversion process in Muntilan began to have solution. This is evident when the production of stone sculptures flourished in Muntilan; many Muntilan communities worked as stone sculptors. Misgiya's notes in 2004 stated that there were 325 crafters and 350 budding craftsmen involved in the production of stone sculptures.

Another factor that establishes the attitude of tolerance of Muntilan community is habituation of internalized environment in each individual, especially in the environment of stone sculpture. The following explanation demonstrates environmental habituation in the internalization of the tolerance of the stone sculpture maker in Muntilan.

The social-cultural environment of negarigung society of the country and the physical environment of Merapi that creates a routine of production of stone sculptures. The environment is the potential for cultural processes (Haviland 1985; Kaplan and Manners 1999; Irianto 2009; Rohidi 2000). The themes of the temple, especially the symbols in Borobudur temples, are a source of inspiration in the work and material from Mount Merapi as a source of the material.

For the stone sculptors in Muntilan, Borobudur temple with various symbols in it is a cultural heritage that must be understood and handed down to each generation. Although their Muslim sculptors are open and willing to create works of non-Moslem religious and cultural symbols, especially Buddhist symbols in Borobudur temple. Stone Sculptors very understand 
the size, technique, and detail of each part of the symbols that exist in Central Java, such as temple ornaments, reliefs, statues, and stupas.

Sculptors can separate religious affairs and job affairs. Despite most of the Muslim sculptors, but still open and willing to create works with religious symbols that are contrary to his belief. Sculptors have a professional attitude by accepting and creating stone-carved work that consumers demand, though different from their beliefs (read interview data above).

In a more plural work environment, people can be tolerant of such diversity. This relates to the functional relationship that is established in the working sector because of the conducive atmosphere in working become a common interest (Rasimin 2016). Things that tend to be avoided in the job environment generally involve too much intervention in the problems that are considered sensitive in the relationship. The makers of stone sculptures only make to order. For the sculptural makers, they make for the satisfaction of art, and the economic work that earns money has nothing to do with religious issues. This shows that the boundaries of tolerance occur with regard to ideological and belief issues.

Tolerance in community groups is harmony between community members. The activity of stone sculpture in Muntilan reflects the attitude and attitudes of the community in seeking harmony among individuals in diversity. Tolerance is a necessity in the realization of harmony among the community members who have a diversity of trust. It is expressed by Rasimin (2016, 112) that the harmony is as a part of the needs of individuals or groups to organize the lives of society, encouraging their attitudes and behaviors in realizing life together harmoniously and peacefully. 


\section{Conclusion}

Muntilan has a socio-cultural background and a plural religion. Communities of Muntilan have become accustomed to diverse lives. The stone craft in Muntilan is the local wisdom of the Muntilan people that is reflecting the value of tolerance. Most of the rock artisans are Islam, but it continued to the Hindu-Buddhist tradition. The product is oriented towards consumer demand in contrast to the beliefs of craftsmen such as Buddha statues, Hindu deities, statues of Jesus, as well as statues of other religions. The craftsmen separated themselves between work and religious issues. It illustrates welcoming attitudes as well as tolerant in accepting and in understanding differences. Local wisdom with a long-standing tolerance value in the community is a potential for community development in realizing a harmonious and peaceful life.

\section{Bibliography}

B. Milles, Matthew, and A Michael Humberman. 2007. Analisis Data Kualitatif. Edited by Tjetjep Rohendi Rohidi. Jakarta: UI Perss.

BPS Magelang. 2017. Kecamatan Muntilan Dalam Angka. Magelang: BPS Kabupaten Magelang. https://doi. org/1102001.3308070.

Geertz, C. 1985. Agama Jawa: Abangan, Santri, Priyayi Dalam Kebudayaan Jawa. Edited by A. Mahasin and B. Rasuanto. Depok: Komunitas Bambu.

Haviland, William A. 1985. Antropologi. Edited by Soekadijo. Jakarta: Erlangga.

Irianto, Agus M. 2009. Epistimologi Kebudayaan. Semarang: Lengkong Cilik Press.

Kaplan, David, and Albert Manners. 1999. Teori Budaya. Edited by Kamdani. Yogyakarta: Pustaka Pelajar. 
Koentjaraningrat. 2002. Kebudayaan Jawa. Jakarta: PN Balai Pustaka.

Kuswarsantyo. 2014. "Seni Jathilan Dalam Dimensi Ruang Dan Waktu." Jurnal Kajian Seni 1 (1): 48-59.

Maulidah, R. 2014. "Toleransi Umat Muslim Terhadap Keberadaan Gereja Pantekosta Di Surabaya." Religió: Jurnal Studi Agama-Agama 4 (2): 195-217.

Misgiya. 2004. "Dari Kerajinan Menuju Ke Kriya Seni Pahat Batu Di Muntilan.” Tesis Universitas Gajah Mada Yogyakarta.

Muchtar, I. H., and H. Burhani. 2016. "Relasi Antara Umat Islam Dan Katolik Di Kelurahan Muntilan, Magelang, Jawa Tengah.” In Relasi Antar Umat Beragama Di Berbagai Daerah, 183-230. Jakarta: Puslitbang Kehidupan Keagamaan Badan Litbang dan Diklat Kementerian Agama RI.

Ningtyas, E. 2018. "Modernitas Di Betlehem Van Java: Kondisi Sosial Muntilan Dan Mendut Awal Abad Ke-20." Mozaik: Jurnal Ilmu-Ilmu Sosial Dan Humaniora 9 (1): 39-50. https://doi.org/10.21831/moz.v9i1.19410.

Parwito. 2019. "Tokoh Lintas Agama Buka Puasa Bersama Di Klenteng Hok An Kiong.” March 5, 2019. 2019.

Rasimin. 2016. “Toleransi Dan Kerukunan Umat Beragama Di Masyarakat Randuacir." Inject: Interdisciplinary Journal of Communicatio 1 (1): 99-118.

Rohidi, Tjetjep Rohendi. 2000. Kesenian Dalam Pendekatan Kebudayaan. Bandung: STISI Bandung.

Ruhana, A. S. 2015. Bersanding Dalam Budaya Relasi Muslim Buddhis Di Panggang, Gunung Kidul, DI Yogyakarta. Jakarta: Puslitbang Kehidupan Keagamaan Badan Litbang dan Diklat Kementerian Agama RI.

Sofiyev, K. 2019. "Multiculture in A New Culturology Thinking." Ponte: International Journal of Sciences and Research 75 (1).

Spradley, James P. 2007. Metode Etnografi. Yogyakarta: Tiara Wacana. 
RELIGIOUS TOLERANCE THROUGH STONE SCULPTURE ...

Supeno, Hadi. 1990. "Djayaprana Sang Maestro Dari Perumpung." Majalah Wacana, 1990.

Triyanto. 2018. Belajar Dari Kearifan Lokal Seni Pesisiran. Semarang: Cipta Prima Nusantara. 
This page intentionally left blank 